\title{
The Effect of Corporate Governance Mechanism on the Financial Performance of Microfinance Institutions Evidence from Ethiopian Microfinance Institutions
}

\author{
Mr. Bekana Dembel \\ College of Business and Economics, Department of Accounting and Finance \\ P. O. Box 334 Bonga, Ethiopia \\ Mr. Mohammed Abdulselam \\ College of Business and Economics, Department of Accounting and Finance \\ P. O. Box 334 Bonga, Ethiopia
}

The research is financed by the authors themselves

\section{Abstract}

The study was aimed to examine the effect of corporate governance attributes on the financial performance of MFIs. Explanatory research design with mixed research approach was employed to carry out the study. From 12 legally registered microfinance institutions at NBE and operating in Addis Ababa city administration, 7 MFIs was purposively selected to investigate the effect of corporate governance variables such as board size, board educational qualification, board experience in the financial sector, meeting frequency of the board, board audit committee size and board independency on the financial performance of MFIs measured by Return on Equity and Operational Self Sufficiency. In addition to main explanatory variables, control variables such as MFIs size, leverage and MFIs age were also included in the study variables. Both primary and secondary data were used in which primary data regarding board characteristics was collected through questionnaire and secondary data was obtained from NBE and AEMFI. Panel data covering six year from 2010-2015 was analyzed for seven microfinance institutions. The regression results revealed that board size, board educational qualification, meeting frequency, board independency and MFIs age have positive and significant relationship with financial performance; whereas board experience in the financial sector and board audit committee size has statistically negative association with MFIs' financial performance. Leverage and the size of microfinance institutions do not have significant impact on the financial performance of Microfinance Institutions. Based on empirical result of the study, it is recommended that board audit committee sizes should be kept low. Furthermore, in order to reduce the problem of management failures which put at risk the money obtained from government and other sources, the governance system of MFIs have to be effective.

Keywords: Corporate Governance Mechanisms, Agency Theory, Financial Performance, MFI

DOI: $10.7176 /$ RJFA/10-21-03

Publication date: November $30^{\text {th }} 2019$

\section{Introduction}

According to the Organization for Economic Cooperation and Development (2004), corporate governance is set of rules that define the relationship between stakeholders, management, and board of directors of a company and influence how that company is operating. It can be also defined as the process carried out by the board of directors, and its related committees, on behalf of and for the benefit of the company's Shareholders and the other Stakeholders to provide direction, authority, and oversights to the management. According to Waseem et al.(2011), corporate governance is basically concerned with ways in which all parties interested in the well-being of the firm (the stakeholders) attempt to ensure that managers and other insiders are always taking appropriate measures or adopt mechanisms that safeguard the interests of the stakeholders. According to Tarek (2007), good corporate governance ensures that the business environment is fair and transparent and that companies can be held accountable for their actions. Conversely, weak corporate governance leads to waste, mismanagement, and corruption. Regardless of the type of venture, only good governance can deliver sustainable good business performance. In corporate governance, the role played by each member can play a pivotal role for the achievement of goal and objectives of the firm. It is high time that corporate governance took a wider perspective; a perspective that does not focused on shareholders wealth maximization only but considering all other stakeholders (Oladipupo et al., 2014).

In Ethiopia there are various microfinance institutions which operate in different parts of the country. According to Association of Ethiopian Microfinance Institutions (2016), currently there are 35 member of MFIs providing microfinance activities in the area of credit delivery, saving, money transfer, and pension payment services in 8 of 11 regional states/ administrative organs of the EFDRE. According to Belete (2015), Ethiopia is a country that has been showing impressive performance in microfinance in Africa. In the past the firm 
performance is assumed to be determined by many factors. But, nowadays the concept of corporate governance becomes the most important discussion in both developed and developing countries. Various corporate governance variables have been measured to assess their effect on financial performance of the firm.

The motives behind this research were: First, there is no sufficient literature relating to the effect of corporate governance attributes on financial performance of MFIs. The review also reveals that there is scarcity of researches that examine the relationship between corporate governance mechanism and operational sustainability of MFIs that is measured by operational self-sufficiency in Ethiopia. Therefore, a strong motivation to investigate empirically, the effect of these attributes on the financial performance of MFIs was the main motivation of the study. Second, the study on the effect of corporate governance variables on financial performance of the firm is also rare in Ethiopia. Hence, a comprehensive study that considers the scarcity of the study is needed to improve lack of research on the issue in Ethiopia that can broaden the literature regarding the concept of corporate governance mechanism and its effect.

\section{Statement of the Problem}

According to Kingsley \& Theophilus (2012), corporate governance has become a topical issue because of its immense contribution to the economic growth and development of the nation. The absence of good corporate governance is a major cause of failure for many well performing companies on their operation; because good corporate governance needs the dedication of parties in the governance system for co-operation and transparency towards the achievement of goals and objectives. This implies that, the absence of teamwork and accountability leads to ineffective and creates doubts between the governing body and the owners so that the financial performance of the firm can be affected. Thrikawala (2013) argued that MFIs which maintain good corporate governance practices will be financially and socially sustainable and reduce risk.

Microfinance industry has vigorous focus on loan to the poor and motivated to extend the frontier of financial intermediation to those excluded from financial market. Therefore, microfinance's governance subjects are not only indispensable but also an essential variable in the bid to uphold the wellbeing of the poor because of their increasing role in controlling significant resources. Many studies introduced the effect of corporate governance on the financial performance and established the relationship between corporate governance variables and profitability by using indicator of financial performance such as ROE and OSS especially in developed countries. However, in developing countries like Ethiopia the issue was not well developed and wellstudied to reveal the influence of corporate governance on the financial performance of the firm.

The Ethiopian microfinance sector is characterized by its rapid growth, an aggressive drive to achieve economies of scale, a broad geographic coverage, a dominance of government backed MFIs, an emphasis on rural households, the promotion of both credit and savings products, a strong focus on sustainability and by the fact that the sector is Ethiopian owned and driven (Ebisa et al., 2013). Studies that have been conducted on the impact of corporate governance on the financial performance of the firm are less in Ethiopia. For instance, Yenesew (2012) studied about the impact of corporate governance mechanisms on banks' financial performance in Ethiopia. Moreover, a few studies were conducted in Ethiopia on the effect of corporate governance on the financial performance of microfinance institutions (Wolday, 2008; Belete, 2015; \& Eyob, 2016). They took corporate governance variables such as board size, board gender composition, board competence, and board experience in the financial sector, meeting frequency, size of the audit committee, CEO duality and CEO gender as variables which affect the financial performance of microfinance institutions measured by ROA and ROE.

Those studies suggested for the future research that the relationship between corporate governance mechanisms and firms' financial performance can also be further explained if future researches conduct study including more corporate governance variables and by adding period of research study. Moreover, previous studies made on this subject area were carried out at country level. However, there were no previous studies that examined the effect of corporate governance on financial performance of MFIs at regional level or city administrative level in Ethiopia. On the other hand, there was no previous study that examined the effect of corporate governance mechanism on financial performance of MFIs measured by OSS in Ethiopia. The concept of corporate governance needs great attention because of its indispensable role in determining the firm performance. Therefore, examining the issue deeply going down from countrywide to region wide/City administration level can broaden the understanding of the effect of corporate governance variables on financial performance of MFIs. In order to fill this gap, the current researcher was acknowledged these suggestions and put in one unique financial performance measurement technique (i.e. OSS) that measures the operational sustainability of MFIs to evaluate corporate governance effect on the financial performance of MFIs operating in Addis Ababa city administration.

\section{Objectives of the Study}

The general objective of this study is to examine the effect of corporate governance attributes on the financial performance of microfinance institutions operating in Addis Ababa City Administration. 


\section{Results and Discussion}

\subsection{Correlation Analysis}

Pairwise correlations analysis is a technique of assessing the relationship among variables selected for the study. The dependent variables that were selected for this study were Return on Equity (ROE) and Operational Self Sufficiency (OSS); and the independent variables were board size, board educational qualification, board experience in the financial sector, meeting frequency of the board, board audit committee size, and size of outside directors that was expected to influence effect variables. The results of the correlation matrix that reveals the degree of association among study variables at different level significance (i.e. $1 \%, 5 \%$ and $10 \%$ ) are depicted in the table 4.6 and table 4.7 below.

\subsubsection{Correlation Analysis of ROE and Board Characteristics Elements}

Correlation matrix below indicates that board size, board educational qualification, meeting frequency, outside directors, board independency and control variables such as MFIs age has a positive correlation with ROE. On the other hand, board audit committee size and board experience in the financial sector has negative association with financial performance. Finally, a control variable such as MFIs' age has also positive and significant correlation with ROE.

\begin{tabular}{|c|c|c|c|c|c|c|c|c|}
\hline Correlatic & on $\mathrm{ROE}$ & $\mathrm{BS}$ & BOEDU & BEFS & MF & $\mathrm{ACS}$ & BIND & LNTA \\
\hline LEV $\mathrm{N}$ & MFIs age & & & & & & & \\
\hline ROE & 1.000000 & & & & & & & \\
\hline BS & 0.001559 & 1.000000 & & & & & & \\
\hline BOEDU & 0.136452 & 0.195697 & 1.000000 & & & & & \\
\hline BEFS & -0.218308 & $0.705976^{*}$ & $0.522345^{*}$ & 1.000000 & & & & \\
\hline $\mathrm{MF}$ & $0.321084^{*}$ & $-0.368930^{*}$ & $0.297740 *$ & -0.182348 & 1.000000 & & & \\
\hline $\mathrm{ACS}$ & -0.106189 & $-0.315917^{*}$ & 0.182583 & 0.175181 & -0.073734 & 1.000000 & & \\
\hline BIND & $0.304255^{*}$ & -0.247055 & -0.019389 & -0.245474 & $0.267670^{*}$ & -0.226723 & 1.000000 & \\
\hline LNTA & -0.001659 & $0.288506^{*}$ & 0.220002 & $0.290375^{*}$ & 0.183392 & -0.221435 & $0.373335^{*}$ & 1.000000 \\
\hline $\begin{array}{l}\text { LEV } \\
1.000000\end{array}$ & $-0.401880^{*}$ & $-0.298222^{*}$ & 0.248602 & $-0.421676^{*}$ & $0.498344^{*}$ & -0.075716 & 0.212742 & 0.086415 \\
\hline MFIs aga & 0.550897 & -0.110715 & -0.045448 & -0.300484 & 0.066972 & 0.060393 & 0.127306 & -0.053260 \\
\hline
\end{tabular}

$0.409004^{*} 1.000000$

Source: Author survey data, 2017 STATA output

Note: 1 . Bold indicates, significant at $1 \%$ level of significance.

2. Italic indicates, significant at $5 \%$ level of significance.

3. A star indicates, significant at $10 \%$ level of significance.

\subsubsection{Correlation Analysis of OSS and Board Characteristics Elements}

The second model is regarding financial sustainability of microfinance institutions measured by Operational Self Sufficiency (OSS). Microfinance institutions can be attained sustainability when their operating income from loan is sufficient to cover all the operating costs. The institutional sustainability of MFIs can be measured by operational self-sufficiency. Therefore, operational self-sufficiency measures operating revenues as a percentage of operating and financial expenses including loan loss provision expense. In this case explained variable is OSS and explanatory variables are board size, board educational qualification, and board experience in the financial sector, meeting frequency of the board, board audit committee size and outside directors were expected to influence the institutional sustainability of MFIs. The control variables included in this model were MFIs' leverage and MFIs age.

The correlation matrix in the table 4.7 below indicates that board size, educational qualification of the board, outside director, meeting frequency of the board and MFIs age have a positive correlation with OSS. This implies the large number of board of directors, educational qualification of the board, outside directors and frequency of board meeting can improve the operational sustainability of MFIs. Control variables (i.e. MFIs age) have significant positive association with OSS. This implies the age of MFIs can improve the operational sustainability of MFIs. On the other hand, sizes of board audit committee, board experience in the financial sector and Leverage have negative correlation with the OSS. This indicates that board audit committee size, board experience in the financial sector and leverage has negatively contributed to the financial performance of MFIs. 


\begin{tabular}{|c|c|c|c|c|c|c|c|c|c|}
\hline $\begin{array}{c}\text { Correlation } \\
\text { OSS }\end{array}$ & OSS & $\mathrm{BS}$ & BOEDU & BEFS & $\mathrm{MF}$ & $\mathrm{ACS}$ & BIND & LEV & MFISAGE \\
\hline BS & $0.260698^{*}$ & 1.000000 & & & & & & & \\
\hline BOEDU & 0.106624 & 0.195697 & 1.000000 & & & & & & \\
\hline BEFS & -0.168786 & $0.705976^{*}$ & $0.522345^{*}$ & 1.000000 & & & & & \\
\hline $\mathrm{MF}$ & 0.123388 & $-0.368930^{*}$ & $0.297740^{*}$ & -0.182348 & 1.000000 & & & & \\
\hline $\mathrm{ACS}$ & $-0.585230^{*}$ & $-0.315917^{*}$ & 0.182583 & 0.175181 & -0.073734 & 1.000000 & & & \\
\hline BIND & 0.232889 & -0.247055 & -0.019389 & -0.245474 & $0.267670^{*}$ & -0.226723 & 1.000000 & & \\
\hline LEV & -0.251698 & $-0.298222^{*}$ & 0.248602 & $-0.421676^{*}$ & $0.498344^{*}$ & -0.075716 & 0.212742 & 1.000000 & \\
\hline MFISAGE & $0.356812^{*}$ & -0.110715 & -0.045448 & $-0.300484^{*}$ & 0.066972 & 0.060393 & 0.127306 & $0.409004^{*}$ & 1.000000 \\
\hline
\end{tabular}

Note: 1 . Bold indicates, significant at $1 \%$ level of significance.

2. Italic indicates, significant at $5 \%$ level of significance.

3. A star indicates, significant at $10 \%$ level of significance

\subsection{Fixed Effect Model and Random Effect Model}

According to Brooks (2008), there are broadly two classes of panel data estimator approaches that can be employed in financial research. These are fixed effect model and random effect model. Fixed effects models allow the intercept in the regression model to differ cross-sectionally but not over time, while all of the slope estimates are fixed both cross-sectionally and over time. An alternative to the fixed effects model described above is the random effects model, which is sometimes also known as the error components model. As with fixed effects, the random effects approach proposes different intercept terms for each entity and again these intercepts are constant over time, with the relationships between the explanatory and explained variables assumed to be the same both cross-sectionally and temporally.

However, the difference is that under the random effects model, the intercepts for each cross-sectional unit are assumed to arise from a common intercept $\alpha$ (which is the same for all cross-sectional units and over time), plus a random variable $i$ that varies cross-sectionally but is constant over time. $i$ measures the random deviation of each entity's intercept term from the 'global' intercept term $\alpha$ (Brooks, 2008). In order to choose and apply the appropriate model, hypothesis was developed and tested by Hausman specification test. The null hypothesis is: random effect model is appropriate and alternative hypothesis is: fixed effect model is appropriate. If p-value is greater than 5 Percent, null hypothesis should be accepted otherwise alternative hypothesis. Based on Hausman specification test for both models, random effect model can be appropriate for the estimation of the model since the p-value of both models is greater than 5 Percent (See: Appendix B and C).

\subsection{Regression Result of the Study}

Under this section the regression model and the discussion of the result was presented. The panel data for six consecutive years of seven MFIs was used to run the regression to investigate the effect of corporate governance on the financial performance of MFIs measured by ROE and OSS. Model one in the table 4.8 below is regarding the relationship between corporate governance and financial performance of MFIs measured by ROE. The overall significance of the model can be seen from regression result of Wald chi2 and its p-value result. The study found that the model is significant which means that the financial performance of MFIs can be influenced by corporate governance mechanism. This conclusion can be supported by the regression result of Wald chi2 and its p-value (i.e. Wald chi2 $(6)=42.10$; p-value $=0.0000$ ) that reveals the model is significant. Moreover, the regression result of random-effects GLS model indicates that the output of multiple panel data regression analysis is found at fairly satisfactory level. This can be evidenced by the overall result of R-squared that reveals $56.81 \%$. This implies that there is a relationship between explained and explanatory variables so that the variation in the dependent variable is well explained by the variation in the explanatory variables of the model. Accordingly, board size, board educational qualification, board experience in the financial sector meeting frequency of the board and MFIs age are statistically significant, whereas, board audit committee size, MFIs size and leverage are not statistically significant.

The second empirical model is regarding operational self sufficiency (OSS) that measures the institutional sustainability of MFIs. The overall result of random-effect GLS model reveals that the model adequately describes the data. It indicates that the model is significant and well fitted that corporate governance mechanism has significant effect on the financial performance of MFIs measured by OSS. This can be evidenced by the regression result of the model that indicates (Wald chi2 $(8)=58.74$ with its p-value of 0.0000 ) so that the model is fairly significant in which the explanatory can influence the dependent variable at 5 percent level of significant. Moreover, the overall R-square that indicates the overall fitness of the model reveals that 64 percent of the variation in OSS was explained by corporate governance and control variables. Since the main objective 
of the study is to investigate the effect of corporate governance on financial performance of MFIs, board characteristics were taken as explanatory variables and MFIs' financial performance was taken as explained variables. Under this section of the chapter the principal implication of the study's result was discussed.

\section{Table 4.8: Regression results of model one}

Random-effects GLS regression

R-sq: within $=0.4085$

Between $=0.9336$

Overall $=0.5681$
Number of obs $=42$

Number of groups $=7$

Obs per group: $\min =6$

$$
\begin{array}{r}
\operatorname{avg}=6.0 \\
\operatorname{Max}=6
\end{array}
$$

Wald chi2 $(6)=42.10$

\begin{tabular}{|c|c|c|c|c|c|c|}
\hline roe & Coef. & $\begin{array}{l}\text { Robust } \\
\text { Std. Err. }\end{array}$ & $\mathrm{z}$ & $\mathrm{P}>|\mathrm{z}|$ & \multicolumn{2}{|c|}{ [95\% Conf. Interval] } \\
\hline bs & .0659041 & .0278725 & 2.36 & 0.018 & .0112749 & .1205333 \\
\hline boedu & .3771218 & .0809543 & 4.66 & 0.000 & .2184543 & .5357893 \\
\hline befs & -.3954427 & .1168987 & -3.38 & 0.001 & -.6245598 & -.1663255 \\
\hline $\mathrm{mf}$ & .0213662 & .0076773 & 2.78 & 0.005 & .006319 & .0364133 \\
\hline boacs & -.3974281 & .3453371 & 1.15 & 0.250 & -.2794203 & 1.074276 \\
\hline bind & .4082796 & .2655945 & 1.54 & 0.0124 & -.112276 & .9288352 \\
\hline lnta & -.1548647 & .2126912 & -0.73 & 0.467 & -.5717319 & .2620024 \\
\hline lev & -.0160138 & .0182957 & -0.88 & 0.381 & -.0518726 & .0198451 \\
\hline MFIs age & .0209566 & .0076094 & 2.75 & 0.006 & .0060425 & .0358707 \\
\hline _cons & -1.323096 & .4610387 & -2.87 & 0.004 & -2.226716 & -.4194772 \\
\hline sigma $u$ & \multirow{2}{*}{\multicolumn{6}{|c|}{ 然 }} \\
\hline sigma_e & & & & & & \\
\hline rho & \multicolumn{6}{|c|}{$0\left(\right.$ fraction of variance due to $\left.u \_i\right)$} \\
\hline
\end{tabular}

Prob $>$ chi $2=0.0000$

Source: Author regression result, 2017 STATA output

Table 4.9: Regression results of model two

Random-effects GLS regression

R-sq: within $=0.0624$

Between $=0.9845$

Overall $=0.6403$
Number of obs $=42$

Number of groups $=7$

Obs per group: $\min =6$

$$
\operatorname{avg}=6.0
$$$$
\operatorname{Max}=6
$$

Wald chi2 (8) $\quad=\quad 58.74$

Prob $>$ chi $=0.0000$

\begin{tabular}{ccccccc}
\hline oss & Coef. & Std. Err. & $\mathrm{z}$ & $\mathrm{P}>|\mathrm{z}|$ & \multicolumn{1}{c}{$[95 \%$ Conf. Interval] } \\
\hline bs & .1360878 & .0540522 & 2.52 & 0.012 & .0301474 & .2420282 \\
boedu & 1.877747 & .6390351 & 2.94 & 0.003 & .6252609 & 3.130232 \\
befs & -1.18337 & .4405914 & -2.69 & 0.007 & -2.046914 & -.3198271 \\
mf & .0158394 & .0199492 & 0.79 & 0.427 & -.0232603 & .0549391 \\
boacs & -1.426861 & .6885219 & -2.07 & 0.038 & -2.776339 & -.0773825 \\
bind & .3615147 & .377549 & 0.96 & 0.338 & -.3784678 & 1.101497 \\
lev & -.0911957 & .0629691 & -1.45 & 0.148 & -.2146129 & .0322215 \\
MFIs age & .0451513 & .0177971 & 2.54 & 0.011 & .0102696 & .080033 \\
cons & -1.029611 & .8030901 & -1.28 & 0.200 & -2.603638 & .5444171 \\
\hline
\end{tabular}

sigma_u 0

sigma_e $\quad .20837857$

rho $\quad 0 \quad$ (fraction of variance due to $\mathrm{u}$ i) 


\subsection{Hypothesis Testing}

Under this section the developed empirical hypothesis of the study was tested. The hypothesis was tested based on the regression result of Random-effect generalized least squares (GLS), with cluster robust standard error using STATA version12.

H01: There is no significant relationship between board size and financial performance of MFIs.

The regression result of the study in the table 4.8 and table 4.9 indicates that there is statistically significant $(\mathrm{P}>|\mathrm{z}|=0.018<0.05)$ and $(\mathrm{P}>|\mathrm{z}|=0.012<0.05)$ positive relationship between board size and MFIs' financial performance measured by ROE and OSS at 5 percent level of significant respectively. This implies that the size of board directors has significant positive effect on financial performance of MFIs. Council of Microfinance Equity Funds (2012) argued that board should be large enough to complete their work effectively (without overburdening members), to provide continuity, and to ensure quorums meeting. Therefore, the result is complements with the view that large boards are more effective in monitoring and controlling MFIs management and help to reduce the agency cost so that the sustainability and profitability of MFIs can be achieved. The empirical result of the study supports the prior empirical finding of different authors that argued increase in board size leads to effective monitoring and supervising the activities of management. Accordingly, the result is consistent with prior studies which argue that larger boards have their benefits and when board size increases firm performance also goes up as more board members provide greater monitoring, advice and make available better linkages to the external environment (Hillman, \& Dalziel, 2003; Daniel et al, 2007; Bassem, 2009; Mersland, \& Strom, 2009; Lukawago, 2012; Chenous et al., 2014; \& Akpan, 2015). Moreover, the finding did not support the argument of Fama \& Jensen (1983) stating that an increase in board size leads to less effective communication and monitoring due to coordination and process problems inherent in large board size. Therefore, the null hypothesis is rejected and board size has significant effect on MFIs' financial performance.

H02: Board educational qualification has no significant relationship with financial performance of MFIs.

Board educational qualification, according to the regression result had statistically significant positive association with ROE and OSS $(\mathrm{P}>|\mathrm{z}|=0.000<0.05)$ and $(\mathrm{P}>|\mathrm{z}|=0.003<0.05)$ respectively. The result of the multiple random-effect GLS regression of the two models indicate that the high proportion of directors who had college degree or higher had a significant positive influence on the financial performance of MFIs. This implies that, the educational qualification of the board directors improve the MFIs' profitability and sustainability since the presence of qualified directors on the board plays an indispensable role in performing the boards' monitoring and supervising that in turn improve the financial performance of MFIs. Thrikawala (2013) provided recommendation that MFIs' boards have to be selected on academic and professional quality so that the monitoring activities would be carried out efficiently and effectively.

The result of the study is consistent with prior studies made by different authors. Accordingly, educational qualification affects the oversight and monitoring role of boards of directors and this also reduces agency cost as well; because directors are required to make an informed decision which requires a thorough understanding (Bassem, 2009; Lukwago, 2012; Mori, \& Olomi, 2012; \& Thrikawala, 2013). Their result indicates that board without appropriate educational qualification cannot contribute to the financial performance of MFIs. Moreover, the educational qualification of the board plays a significant role at the time of analysis and interpretation of information and data which is important for the effective strategic guidance of the operation of MFIs and the effective control or monitoring of management by board of directors. Generally, according to the results of the study educational qualification of the board of directors as measured by the percentage of directors who had college degree or higher significantly influences Microfinance Institutions profitability and sustainability. Therefore, the null hypothesis is rejected and board educational qualification has significant effect on the financial performance of MFIs.

H03: Board's experience in the financial sector has no significant relationship with the financial performance of MFIs.

Board experience in the financial sector implies the board's job experience in the financial sectors. The regression result regarding board experience in the financial sectors for both ROE and OSS is negative (coefficient of -0.3954427 and -1.18337 respectively) that indicate there is a negative relationship between board experience with financial sector and MFIs' financial performance. This implies that board experience in the financial sector is statistically not significance relationship with $\operatorname{ROE}$ and $\operatorname{OSS}(\mathrm{P}>|\mathrm{z}|=0.001<0.05$ and $\mathrm{P}>|\mathrm{z}|=$ $0.007<0.05$ respectively) at 5 percent level of significance.

The empirical result obtained by this study did not support the prior studies finding that the higher the proportions of directors who had earlier working experience in the financial sector the better the financial performance of MFIs (Valentina, 2005; Bassem, 2009; \& Durgavanshi, 2014). They conclude that, in order to be strategic resource of the firm, board need to be skillful. However, the finding of this study was not consistent with those findings because the management system is specific to the countries. This means that what is applied in most developed countries cannot be applied in developing countries. Regarding corporate governance system in developing countries, it was not well developed and the awareness concerning the governance principles 
under corporate governance was not well understood in developing countries including Ethiopia. As a result, board members of most of MFIs in Ethiopia do not have awareness of the concept of corporate governance and hence do not apply best practices of corporate governance in their respective MFIs. In addition, the board members of government owned MFIs play dual role so that they carry out political issue in addition to monitoring the activities of manager.

Therefore, according to the finding of this study, the mere experience of the board in the financial sector cannot contribute to the financial performance of the firm. Moreover, most of the boards are recruited from outside that are serve as the board member of different organizations so that they are financially strong. The result of the study is consistent with the finding of Xie et al. (2001) found that outside directors with corporate background are more likely to be financially sophisticated and their presence is associated with a reduced level of earning management. As a result, the null hypothesis is rejected and board experience in the financial sector has significant effect on the financial performance of MFIs.

H04: There is no significant relationship between meeting frequency of the board and financial performance of MFIs.

The concept of meeting frequency in corporate governance refers to the frequency of time that the boards meet in a year. Boards should regularly meet in executive session without management present to discuss matters that may be particularly sensitive regarding management (Council of Microfinance Equity Fund, 2012). Moreover, for board to effectively perform its oversight function and monitor management performance, the board must hold a regular meeting. The result of the regression depicts that meeting frequency is positively associated with financial performance of MFIs. According to the study finding, it improves financial performance specially ROE with $\mathrm{P}>|\mathrm{z}|=0.005$ which is less than 5 percent and indicates the more board is meet frequently the higher financial result of MFIs. In addition, the relationship between board meeting frequency and OSS is positive but the effect of meeting frequency is insignificant.

The finding of this study was in line with prior studies that one of the measure of board effectiveness in monitoring the activities of manager can be indicated by the frequency of meeting they performs (Karamanou \& Vefeas, 2008; Mangena \& Tauringana,2008; \& Ntim \& Osei, 2011). They conclude that frequent board meetings can result in higher qualities of management monitoring that in turn impact positively on corporate financial performance. However, the finding of the study contrasted the result of Akpan (2015) that reports a statistical significance and negative association between frequency board meetings and corporate performance which means that the frequency of meetings reduced shareholders earnings as company incurred more financial expenses in terms of sitting allowance, travelling expenses, hotel accommodation and entertainment during meetings. As a result, the null hypothesis is rejected and board of directors' meeting frequency has significant effect on the financial performance of MFIs.

H05: Size of audit committee has no significant effect on the financial performance of MFIs.

Size of audit committee according to this study is the percentage of the board that was included in the audit committee of the MFIs and responsible for oversight of the financial reporting process, selection of the independent auditor, and receipt of audit results of both internal and external auditors. The size of audit committee is negative insignificant relationship with ROE. However, the finding is not consistent with studies of (Bassem, 2009; Lukwago, 2012; \& Danoshana, \& Ravivathani, 2013). They pointed out that increasing audit committee size will result high financial performance; because detailed discussion on the financial statement of the companies will lead to get more ideas regarding the reports and it will guide to increase the firm's performance.

However, there is statistically significant negative relationship between OSS and size of board audit committee $(\mathrm{P}>|\mathrm{z}|=0.038<0.05)$. This implies that as the percentage of board that included in the audit committee increases, the operational self sufficiency which measures the operational sustainability of MFIs is reduces. It is impossible to conclude that the only presence of audit committee improve their effectiveness in performing its oversight role. This may be due to inefficient of the board member included in the audit committee since they serve as dual role (i.e. as board member and as audit committee member) which make them ineffective. This result is consistent with Xie et al., (2001) that found the performance of the audit committee was determined by its size. In cases where the audit committee was large, it suffered from the problem of free riders and a higher probability of members to be more vulnerable to the pressures and more subject to follow other members' opinion without giving another argument. As a result, the null hypothesis is rejected and board audit committee size has significant effect on the financial performance of MFIs.

H06: Board independency has no significant effect on the financial performance of MFIs.

Independent Director means a director who has no direct or indirect material relationship with the company other than membership on the board. The regression result of the study depicts that outside directors has a positive coefficient ( 0.4082796 and 0.3615147 as performance is measured by ROE and OSS) showing that the more proportion of outside directors the higher the financial performance of MFIs. This implies that the monitoring and supervising of the board is improved when they are not associated with MFIs as employee or have no share 
from MFIs as conflict of interest is minimized since they are not the full member of management.

The result of the study is in line with the prior finding that found there is a positive relationship between MFIs' financial performance and outside directors. Those studies concluded that with their knowledge and experiences, outside directors can enhance firm's performance, as well as protect shareholders' interest through effective decision making (Valentina, 2005; Sharon, 2006; Bassem, 2009; Al-Sahafi et al., 2015). However, the finding of the study contradicts the conclusion of Mori \& Olomi (2012) that it does not matter whether the members of MFI boards are either externally or internally (employees and affiliates) sourced. Agency theory is highly concerned about board independence and the balance between executive and non-executive directors on the board. The theory recommends that the board of directors is expected to be made up of more non-executive directors (NEDs) for effective control since this reduces conflict of interest and ensures a board's independence in monitoring and passing fair and unbiased judgment on management (Jensen \& Meckling, 1976). Consequently, the null hypothesis is rejected and outside directors has significant effect on the financial performance MFIs.

\section{Control Effect and MFIs Financial Performance}

Under this section the effect of control variables on the financial performance of microfinance institutions was discussed. The control variables selected for the study and expected to influence financial performance of MFIs are size of MFI, leverage and age of MFIs. In addition to what has been discussed above, the regression result of the two models depict the result of the regression analysis between control variables and financial performance indicators of sample MFIs which are interpreted below.

The regression result of the study reveals that there is a significant positive relationship between MFIs age and their financial performance. The model coefficient of the two models $(0.02099266$ and 0.0451513 for ROE and OSS respectively) indicate that as microfinance stay in the market for long period of time, their financial performance can be improved through time as they learn more about the techniques how service can be provided and use them to innovate the methods of providing services to the public. Kipesha (2013) argued that the age of microfinance institution has influence to their financing needs; the older institutions are at an advantage of acquiring commercial financing as compared to new established Microfinance institutions. The age of Microfinance institutions is also associated with low failure rates due to the resources they possess, goodwill created in the market over time as well as legitimacy created in the market place. The older Microfinance institutions have acquired knowledge and experience about the market, the better operational strategies, financing sources, customer needs and have learned ways to overcome competition constraints in the market.

Regarding leverage, the study found that insignificant negative relationship with financial performance of MFIs as measured by ROE and OSS. This implies that leverage has no significant effect on performance of microfinance institutions. Katsushi et al. (2011) argued that high leverage stands the risk of long term sustainability given heavy reliance on debt; the opportunity to access borrowed funds can be harnessed for expansion of MFIs. The empirical evidences made in different countries indicate different findings regarding the effect of leverage on firm performance. Weill (2003), who carried out new empirical evidence on a major corporate governance issues, the relationship between leverage and corporate performance found mixed evidence depending on the country; while significantly negative for firms in Italy, the relationship between leverage and corporate performance is significantly positive for firms in France and Germany. On the other hand, Majumdar \& Chhibber (1999) also tested the relationship between leverage and corporate performance on a sample of Indian companies by adopting an accounting measure of profitability, return on net worth, to evaluate performance and they observed a significant negative association between leverage and corporate performance. But, the study on Japanese firms by Hirotsugu \& Hitoshi (2003) found a positive relationship with leverage and firm performance. Studies from Microfinance institutions operation around the world have also provided mixed evidences on the impact of size and age on firm performance. According to the study by Cull et al. (2007), Bogan et al. (2008), and Abayie et al. (2011) reveals that the age of Microfinance institutions have a positive effect on their performance in terms of efficiency, sustainability and profitability. The evidences provided by Coleman (2007) also were contrary to most of the empirical findings on the impact of age on Microfinance performance. The study reported a positive impact between age and default rate in Microfinance institutions. The study supported the findings on the ground that as the age increases the institutions expands and reaches more poor clients. Empirical evidences have also shown the presence of positive impact on the size of MFIs on firm performance measured in different aspects.

The study made by Ejigu (2007) reported a positive impact of size on the profitability and sustainability of MFIs in Ethiopia. This result was in line with results by Coleman (2007) which indicated that firm size has a positive impact on yield on gross loan microfinance institutions. Contrary to these findings, Bassem (2008) reported a negative relationship between size and Microfinance institution's efficiency. The relationship between firm size and age is also of great importance in Microfinance institutions. Due to outreach to the poor focus, most of the Microfinance institutions depend much on grants, donations and other forms of subsidies especially 
at start up phase. As the Microfinance institutions grow in term of their size and experience, they are expected to operate more efficiently and sustainable with less dependent on subsidies from donors (Armendariz \&Morduch, 2004).

\section{Summary, Conclusion and Recommendations Summary and Conclusion}

The findings of the study indicate that all the corporate governance elements did not affect the performance of MFIs in the same way. In order to be consistent with the objective of the research, the study identified variables of corporate governance mechanisms such as size of the board, educational qualification of the board, board experience in the financial sector, meeting frequency of the board, board audit committee size and independent director as independent variables, and MFIs' size, leverage and MFIs' age as control variables. The Pairwise Correlations and regression analysis was also used to find out whether there is a relationship between the variables to be measured (i.e. corporate governance and MFIs financial performance) and also to find out whether the relationship is significant or not.

As financial performance indicators the study used Return on Equity (ROE) and Operational Self Sufficiency (OSS) as dependent variables. The table of descriptive statistics result indicates that the financial performance of sample MFIs are 13.48 percent and 129.29 percent as measured by ROE and OSS respectively, indicating that the sample MFIs are better in covering their operational costs by using their operational revenues than utilizing shareholders' funds. On the other hand, the descriptive statistics result of board characteristics of MFIs are generally characterized by having an average board size of 7, an average of 95.15 percent of the directors have college degree and above, 70.38 percent of directors were experienced in the financial sector and 38.08 percent were member of audit committee. In addition, the board meets on average 7 times in a year which is less than the suggestion by NBE which is 12times for meeting of MFIs per annum. Pairwise correlations analysis table of the study depicts that boar size, board educational qualification, meeting frequency, board independency are positively associated with ROE. However, board experience in the financial sector and board audit committee Size were negatively correlated with ROE. From the control variables, MFIs age of sample MFIs is also positively correlated with ROE. On the other hand, board size, educational qualification of the board, frequency of board meeting and outside directors are positively correlated with OSS. In contrast to this, board experience in the financial sector and board audit committee size is negatively associated with OSS. In addition, MFIs age is positively correlated with operational self-sufficiency.

The hypotheses were tested from random-effect GLS regression models. According to the regression result of the study, from the explanatory variables board size, board educational qualification, board experience in the financial sector, meeting frequency, board independency and MFIs age were found to be significant regressors of performance of sample MFIs as measured by ROE; whereas board size, board educational qualification, board experience in the financial sectors, board audit committee size and MFIs age were significantly influence financial performance measured by OSS. However, the study found statistically insignificant relationship between board audit committee size, MFI size and leverage and ROE, and also no significant relationship between meeting frequency of the board, board independency and leverage with OSS.

The study found that there is a positive relationship between the size of the board and educational qualification of the board and financial performance of MFIs measured by ROE and OSS. The result indicates that the larger board member and high proportion of directors who had college degree or higher have a significant positive influence on the financial performance of MFIs. Thrikawala (2013) point out that there must be guidance for selecting directors for MFI boards based on their academic and professional qualifications. According to previous empirical study qualified board plays a vital role in monitoring and overseeing the activities and decision of the firm. This implies that the board with sufficient educational qualification can easily understand and interpret different reports prepared by management, which are vital to enhance performance. Board experience in the financial sector has negative association with financial performance measured by return on equity (ROE) and operational self-sufficiency (OSS). This implies the role of board members with experience in the financial sector can be extended to reduce the financial performance and impact for the betterment of MFIs' overall performance. Regarding meeting frequency of the board, it is positively and significantly influence on financial performance. Mangena \& Tauringana (2008) and other previous studies found that frequent and regular board meeting can result in higher in quality of management monitoring which in turn impact positively on corporate financial performance. This implies that boards should regularly meet in executive session to discuss matters that may be particularly sensitive regarding management which in turn improve the financial performance of MFIs. The regression result of the study revealed that board audit committee size has statistically significant negative relationship with performance as measured by OSS and positive insignificant effect on ROE. This implies that when the number of the board included in the audit committee is increase, the financial performance of MFIs goes in reverse direction. Board independency, according to the finding of the study has a positive relationship with financial performance of the sample MFIs. 
This implies that the monitoring and supervising of the board is improved when they are not associated with MFIs as employee or have no share from MFIs as conflict of interest is minimized since they are not the full member of management.

To sum up, the results of the study indicated that good corporate governance structure plays an imperative role in improving the financial performance of MFIs. This study presented the first evidence on the link between governance mechanisms and financial performance in microfinance institutions. Empirical result of the study evidenced that the corporate governance mechanism and its effect on financial performance is characterized by reasonable board size that reduce overburdening members that improve their monitoring, advising and making available better linkage to the external environment that results better financial performance of MFIs. In addition, educational qualification of the board, meeting frequency and outside directors influence financial performance positively; whereas board experience in the financial sector and board audit committee size influence performance negatively. Finally, agency theory offers a general good explanation of the associations between corporate governance mechanisms and financial performance of the firm.

\section{Recommendations}

The foremost purpose of this study was to examine the effect of corporate governance on the financial performance of MFIs operating in Addis Ababa city administration. Both theoretical as well as empirical evidence that support and against the findings of the study was reviewed. Based on the findings of the study and conclusion arrived, the following recommendations were forwarded to the concerned body.

First, compare to other sectors, effective governance in the financial sector is more important since the sector needs great attention because of its importance in keeping on the track the country's economy. The main reason why financial sector needs greater attention regarding its governance is that they held money from the public as deposit that they in turn provide loans to the deficit parties who want to invest in different investment area. As a result microfinance institutions need to strengthen the corporate governance principles which guide the responsibilities of the board of directors, the chairpersons, CEOs, senior management, board appointed committees, auditors, shareholders and regulators. Because governance is said to be all about effective if it is transparent and accountable administration of affairs of an institution by its management while protecting the interests of its stakeholders including shareholders, creditors, regulators and the public. More specifically, effective governance is needed for MFIs as they are the major economic driving force in developing economy. The following points are the some of the major reasons why greater consideration regarding governance of MFIs is needed.

$\checkmark$ Their major liabilities are generated from funds raised mainly through deposits from the public, mainly from the poor that require greater fiduciary responsibilities on MFIs and its directors since depositors' funds need to be safeguarded.

$\checkmark \quad$ Like other financial institutions, MFIs also serve as intermediaries between savers and investors by lending funds they accept as deposit from the public to the investors who need to spend on different area of economy.

$\checkmark$ MFI is one of the members of financial institutions; they need to perform their activities in a manner that keep public confidence since loss of public trust leads to financial crisis that in turn leads to economic crisis.

Second, good corporate governance in the MFIs plays an important role in improving their financial performance, improving transparency, accountability, sustainability, profitability, efficiency, effectiveness, responsibility and responsiveness to the changing environments. Effective corporate governance depends on both structures and processes of control, and content and specific individuals involved, particularly in the leadership. Board of director is the major management organ which plays a critical role in ensuring good governance of MFIs to ensure their profitability and sustainability. Therefore, the laws and codes of conduct that have been recently designed to guide the conduct of firm regarding corporate governance should be designed and implemented in order to oversight the size, composition, qualification and experience of the board member that monitor the activity of the management. Third, publication of manual rules of corporate governance and make available for information the public needs in order to benefit from the application of rules by the management and employees and the various activities of the firm. To do so, NBE needs to set up a unified corporate body burden with the responsibility of collecting corporate governance related data and constructing the relevant indices to facilitate corporate governance research in Ethiopia.

Fourth, on the basis of the above, the authors recommend that the approach to microfinance governance be broadened by focusing to a greater extent on an MFI's stakeholders and the decision-making process within the MFI. This will likely yield a better insight into the way in which MFIs are really managed. Fifth, educational qualification of the board directors improve the MFIs' profitability and sustainability and since the presence of qualified directors on the board plays an indispensable role in performing the boards' monitoring and supervising that in turn improve the financial performance of MFIs. Therefore, MFIs should give great consideration to have 
board of directors with a college degree or above to obtain benefits from well qualified directors. Sixth, board size needs to be large in number, adhering to the minimum requirement of National Bank of Ethiopia which is seven, to an optimal level with better educational qualification, since large board size with better educational qualification is more effective in monitoring and overseeing the management and help to improve performance. Moreover, the larger the number of board of directors the greater is its contribution for performance as revealed by this study

Finally, the size of audit committee should be small so that there would be a smooth communication and a simple and transparent decision making process, which contributes in improving their performance. As the result, audit should be appropriate in size to provide shareholders with periodic reports on changes affecting the shareholders in the company, and held regular meetings with members of the board of directors ensuring that their role should be done to share in the responsibility. Because, as this study revealed, large size of an audit committee negatively affects performance and may not play its role effectively in mitigating the risk of fraud and misrepresentation of the information and improve monitoring and transparency in operations which lead to timely and accurate reporting of the loan defaults and poor performance in an MFI.

\section{References}

Abayie, E., Amanor, K., \& Frimpong, J. (2011). The measurement and determinants of economic efficiency of microfinance institutions in Ghana: A stochastic frontier approach. African Review of Economics and Finance, 2(2), 149-166.

Abdullah, H., \& Valentine, B. (2009). Fundamental and ethics theories of corporate governance. Middle Eastern finance and economics journal, 89-96.

ACCA. (2012). Corporate governance: The board of directors and standing committees

AEMFI. (2016). Organization statement: Association of Ethiopian Microfinance Institutions. Addis Ababa, Ethiopia.

Ahmad, N., \& Sana I. (2015). Financial performance and corporate governance in microfinance: Who drives who? Evidence from Asia.

Ahmadu, U., \& Aminu, S. (2008). Board independence and firm financial performance: Evidence from Nigeria.

Akpan, E. (2015). Corporate board meetings and company performance: evidence from Nigerian quoted companies. G.J.C.M.P., 4(1), 75-82.

Al-Sahafi, A., Rodrigs, M., \& Barnes, L. (2015). Does corporate governance affect financial performance in the banking sector? International Journal of Economics, Commerce and Management, 3(3), 1-26.

Andi, D., \& Guiseppe, T. (2010). The role of ownership identity on the performance of microfinance Institutions.

Armendariz, \& Morduch. (2004). Microfinance: Where do we stand? In Charles Goodhard Edition, Financial Development and Economic Growth, Explaining the Links. UK: London Palgrave.

Aymen, A., Mohamed, K., \& Abderrazak, E. (2014). Board structure and firm performance: evidence from French firms listed in sbf 120. International Journal of Economics and Financial Issues, 4(3), 580-590.

Balsmeier,,B., \& Czarnitki, D. (2011). How important is Industry-Specific Managerial Experience for Innovative Firm Performance?

Baltagi, B. (2005). Econometric analysis of panel data. New Delhi, India: Wiley Publication.

Bassem, B. (2008). Efficiency of microfinance institutions in the Mediterranean: An application of DEA. Transit Stud Rev, 15(4), 343-354.

Bassem, B. (2009). Governance and performance of microfinance institutions in Mediterranean countries. Journal of Business Economics and Management, 10(1), 31-43.

Belete Zegeye, (2015). The impact of corporate governance on microfinance institutions financial performance in Ethiopia. M.Sc Thesis. Addis Ababa University, Addis Ababa

Bello, L. (2012). Board dynamics and corporate performance: review of literature, and empirical challenges. International Journal of Economics and Finance, 4(1), 22-35.

Bogan, V., Johnson, W., \& Mhlanga, N. (2008). Does Capital Structure Affect the Financial Sustainability of Microfinance Institutions?

Brooks, C. (2008). Introduction to econometrics for finance. New York, USA: Cambridge University Press.

Chenuos, K., Mohamed, A., \& Bitok, K. (2014). Effects of corporate governance on microfinance institutions financial sustainability. European Journal of Business and Management, 6(30), 71-82.

Coleman, A. (2007). The impact of capital structure on the performance of microfinance institutions. The Journal of Risk Finance, 8(1), 56-71.

Council of Microfinance Equity Fund. (2012). The practice of corporate governance in microfinance institutions: Consensus statement of the council of microfinance equity funds.

Creswell, J. (2003). Research design: qualitative, quantitative, and mixed approach. London, England: Saga publication.

Creswell, J. (2014). Research design: qualitative, quantitative, and mixed approach. London, England: Saga 
publication.

Cull, R., Demirguc, K., \& Morduch, J. (2007). Financial performance and outreach: A global analysis of leading micro banks. The Economic Journal, 117, 107-133

Daniel, N., Coles, L., \& Naveen, L. (2007). Boards: Does one size fit all? Journal of Financial Economics, 87(2), 329-356.

Danoshana, S., \& Ravivathani, T. (2013). The impact of the corporate governance on firm performance: A study on financial institutions in Sri Lanka. Merit Research Journal of Accounting, Auditing, Economics and Finance, 1(6), 118-121.

Domnick, S., \& Derrick, R. (2001). Theory and problems of statistics and econometrics. New York, USA: McGraw-Hill publication.

Durgavanshi, S. (2014). Impact of corporate governance practices on financial performance of microfinance institutions in India.

Ebisa Deribie, Getachew Nigusie, \& Fikadu Mitiku, (2013). Filling the breach: Microfinance. Journal of Business and Economic Management, 1(1), 010-017.

Ejigu, L. (2009). Performance analysis of sample microfinance institutions in Ethiopia. International NGO Journal 4(5), 287-298.

Eyob Melkamu, (2016). Effects of corporate governance on the financial performance of micro finance institutions in Ethiopia. M.Sc Thesis. Addis Ababa University, Addis Ababa.

Fama, E., \& Jensen, M. (1983). Agency problems and residual claims. Journal of Law and Economics, 26(2), 327-349.

Field, A. (2005). Discovering Statistics Using SPSS. London, England: Sage publication.

Freeman, R., Andrew, C., \& Wicks, P. (2004). Stakeholder theory and the corporate objective revisited. Organization Science, 15(3), 364-369. http://dx.doi.org/10.1287/orsc.1040.0066

Gujarati, D. (2004). Basic econometrics. New York, USA: McGraw-Hill Company publication.

Habbash, M. (2010). The effectiveness of corporate governance and external audit on constraining earnings management practice in the Uk,Durham theses, Durham University.Available at Durham E-Theses Online: http://etheses.dur.ac.uk/448/

Hillman,.J., \& Dalziel, T. (2003). Boards of directors and firm performance: integrating agency and resource dependence perspectives. Academy Of Management Review, 28(3), 83-96.

Hirotsugu, S.,\& Hitoshi, A. ( 2003). The Japanese corporate governance system and firm performance: Toward sustainable growth.

Hussien, A. (2012). Overview of corporate governance in Ethiopia: The role, composition and remuneration of boards of directors in share companies. Mizan Law Review, 6(1), 45-76.

Irene, B., \& Albert, A. (2013). Microfinance in Ghana: Development, success factors and challenges. International Journal of Academic Research in Accounting, Finance and Management Sciences, 3(4), 153160.

Jensen, M., \& Meckling, W. (1976). Theory of the firm: Managerial behavior, agency costs and ownership structure. Journal of Financial Economics, 3(4), 305-360.

Karamanou, I., \& Vefeas, N. (2005). The Association between Corporate Boards, Audit Committees, and Management Earnings Forecasts: An Empirical Analysis. Journal of Accounting Research, 43(3), 453-486.

Katsushi, S., Raghav, G., Ganesh, T., Samuel, K., \& Aditi, G. (2011). Performance of microfinance institutions: A macroeconomic and institutional perspective.

Kingsley, T., \& Theophilus, W. (2012). Corporate governance and firm performance: evidence from the insurance sector of Ghana. European Journal of Business and Management, 4(13), 95-112.

Kipesha, E. (2013). Impact of size and age on firm performance: Evidence from microfinance institutions in Tanzania. Research Journal of Finance and Accounting, 4(5), 105-116.

Kothari, R. (2004). Research methodology. New Delhi, Indian: New age international publishers.

Kyereboah, C. (2007). Corporate governance and firm performance in Africa: A dynamic panel data analysis.

Lascelles, D., Mendelson, S., \& Rozes, D. (2014). The survey of microfinance risk. Centre for the Study of Financial Innovation (CSFI) publication.

Lukawago, J. (2012). Corporate governance and financial performance/growth of microfinance institutions in the case of microfinance institutions under the association of microfinance institutions Uganda. Makerere University.

Majumdar, S., \& Chhibber, P. (1999). Capital structure and performance: evidence from a transition economy on an aspect of corporate governance. Public Choice, 98 (3), 287-305.

Mangena, M., \& Tauringana, V. (2008). Corporate boards, ownership structure and Firm performance in an environment of severe political and economic uncertainty. British accounting association conference. Blackpool.

Melvin, A. (2001). Corporate governance in Africa: The record and policies for good governance. Economic 
research papers.

Mersland, R., \& Strom, R. (2008). Performance and governance in microfinance Institutions.

Mersland, R., \& Strom R. (2009). Performance and governance in microfinance institutions. Journal of Banking and Finance, 33(4), 662-669.

Moenga, G. (2015). The effect of corporate governance on the financial performance of microfinance institutions in Kenya.

Mori, N., \& Olomi, D. (2012). The effect of boards on the performance of microfinance institutions: Evidence from Tanzania and Kenya.

National Bank of Ethiopia.(2012). Microfinance institutions supervision directorate. Addis Ababa. Ethiopia

National Bank of Ethiopia. (2014). Licensing and supervision: Corporate governance directives. Addis Ababa. Ethiopia.

Ntim, G., \& Osei, A. (2011).The Impact of Corporate Board Meetings on Corporate Performance in South Africa. Collins G. Ntim; Kofi A. African Review of Economics and Finance, 2(2).

Oranization for Economic Co-operation and Development. (2004). Principles of corporate governance. Paris, France: Author.

Oladipupo, S., Satirenjit, J., \& Mohd, I. (2014). Holistic approach to corporate governance: A conceptual framework. Global Business and Management Research: An International Journal, 6(3), 251-255.

Otieku, J., \& Aboagye, A. (2010). Are Ghanaian MFIs' performance associated with corporate governance?. The International Journal of Business In Society, 10(3), 307-320.

Raheel, G., \& Amna, B. (2015). Effect of corporate governance on performance of microfinance institutions: A case from Pakistan, emerging markets finance and trade, 51:sup6, S94-S106, DOI: 10.1080/1540496X.2015.1080559.

Salim, D. (2013). Board members' education and firm performance: evidence from a developing economy. International Journal of Commerce and Management, 23(2), 113-135.

Sharon, O. (2006). Defining who is an 'independent director'. Bader and associates governance consultance, 6(1). Stock, J. \& Watson, M. (2003). Introduction to econometrics. Boston: Pearson Addison Wesley.

Tarek, Y. (2007). Corporate governance: An overview-around the globe.

Thankom, A. (2010). Microfinance regulation and social protection. European report on development.

Theirno, B., \& Ruth, T. (2011). Governance and performance: Evidence from African microfinance institutions.

Thrikawala, S. (2013). Corporate governance and performance relationship in microfinance institutions (MFIs). Asian Journal of Finance \& Accounting, 5(1), 160-182.

Thrikawala, S. (2016). Corporate governance and performance of microfinance institutions: A comparative study in Sri lanka and India.

United Nation. (2013). Microfinance in Africa: Overview and Suggestions for Action by Stakeholders.

Valentina, H. (2004). Governance and performance of microfinance institutions in Central and Eastern Europe and the newly independent states.

Valentina, H. (2005). Governance and performance of microfinance institutions in Central and Eastern Europe and the newly independent states.

Varottil, U. (2014). Microfinance and the corporate governance conundrum. Berkeley Business Law Journal, 9(1), 241-292.

Wang, Y., Thsai, J., \& Lin, H. (2013). The influence of board structure on firm performance. Journal of Global Business Management, 9(2), 7-14.

Waseem, A., Saleh, A., \& Fares, A. (2011). The effect of corporate governance on the performance of Jordanian industrial companies. International journal of Humanities and Social Science, 1(4), 55-69.

Weill, L. (2003). Leverage and corporate performance: A frontier efficiency analysis

Wikipedia. (n. d.). History of Addis Ababa. Retrieved from http://en.wikipedia.org/wiki/Addis Ababa.

Wolday Amha, (2008). Corporate governance of the deposit taking MFIs in Ethiopia: The association of Ethiopian microfinance institutions (AEMFI). Addis Ababa, Ethiopia.

Xie, B., Davidson, W., \& Dadalt, P. (2001). Earnings management and corporate governance: The roles of the board and the audit committee

Yenesew Ferede, (2012). The impact of corporate governance mechanisms on firm's financial performance: Evidence from Commercial Banks in Ethiopia. M.Sc Thesis. Addis Ababa University, Addis Ababa.

Zabojnikova, G.(2016). The audit committee characteristics and firm performance: Evidence from the UK. 